\title{
Analysis on Variation Characteristics of Agro-Climatic Resources in Weixian County, China in Recent 54 Years
}

\author{
Liandong Xiang, Zhitao Liu, Xujun Li \\ Weixian Meteorological Bureau, Xingtai, China \\ Email:601020306@qq.com
}

How to cite this paper: Xiang, L.D., Liu, Z.T. and Li, X.J. (2016) Analysis on Variation Characteristics of Agro-Climatic Resources in Weixian County, China in Recent 54 Years. Journal of Geoscience and Environment Protection, 4, 126-141. http://dx.doi.org/10.4236/gep.2016.412010

Received: November 16, 2016 Accepted: December 13, 2016

Published: December 16, 2016

Copyright $\odot 2016$ by authors and Scientific Research Publishing Inc. This work is licensed under the Creative Commons Attribution International License (CC BY 4.0).

http://creativecommons.org/licenses/by/4.0/ (c) (†) Open Access

\begin{abstract}
Based on the daily temperature, precipitation and sunshine data of the National Weather Station of Weixian County, Hebei, China from 1961 to 2014, the average temperature, accumulated temperature, precipitation and sunshine trends of the year and four seasons were analyzed. The results showed an upward trend of the average annual temperature, average annual maximum temperature and average annual minimum temperature and the minimum temperature increase is the largest. The average temperature in summer is decreasing, while the average temperature, maximum temperature and minimum temperature in spring, autumn and winter showed an upward trend. $\geq 0^{\circ} \mathrm{C}$ accumulated temperature increased by $193.82^{\circ} \mathrm{C}$ for 54 years, and $\geq 10^{\circ} \mathrm{C}$ accumulated temperature increased $54.59^{\circ} \mathrm{C}$ for 54 years. Weixian County sunshine hours were $119.121 \mathrm{~h} / 10$ years to reduce the rate of adverse effects on crop growth; annual precipitation decreased by $116.4 \mathrm{~mm}$ for 54 years, the maximum precipitation decreased by $8.2 \mathrm{~mm}$, and the number of annual precipitation decreased $18.6 \mathrm{~d}$, which caused great pressure on groundwater recharge.
\end{abstract}

\section{Keywords}

Weixian County, Climatic Resources, Change

\section{Introduction}

In recent years, the rapid global warming is an indisputable fact, and the 1880-2012 global average surface temperature increased by about $0.85^{\circ} \mathrm{C}$. Global climate change caused widespread concern of governments and the public [1] [2]. At the same time, global warming is accompanied by an increase in local extreme weather and climate events. In North China, northeast, northwest and other regions of China, a higher 
temperature increases in winter and spring warming significantly, and the minimum temperature increase is more pronounced [3]-[8]. In Hebei, the mean temperature of the four seasons shows a linear increase trend, and the minimum temperature increases above the maximum temperature [9] [10] [11]. Weixian County is located in the south of Hebei Province, China. It belongs to Heilonggang Basin. In recent years, the temperature has risen and the rainfall has been reduced. This has accelerated the development of crops and shortened the growth period, thus adversely affecting the local economic and social development. It is important to study the response of Weixian under global climate change and understand the climate change rules in Weixian, which are of great reference significance to the local agricultural modernization and planting structure adjustment.

\section{Materials and Methods}

The climatic data such as temperature, precipitation and sunshine were selected for 54 years from 1961 to 2014 in Weixian National Weather Station. The four seasons were divided into spring (March to May), summer (June to August), autumn (September to November), winter (December-the following February). The trend and significance of the factors were analyzed by the methods of linear regression, moving average, correlation analysis and trend coefficient test.

Average annual maximum (minimum) temperature is for the mean of daily maximum (minimum) temperatures in the whole year. A correlation coefficient is a number that quantifies some type of correlation and dependence, meaning statistical relationships between two or more random variables or observed data values.

\section{Results and Analysis}

\subsection{Years Temperature Change Characteristics}

The average annual temperature in Weixian County is $13.42^{\circ} \mathrm{C}$, the maximum is $14.49^{\circ} \mathrm{C}$ (1998), the minimum is $12.22^{\circ} \mathrm{C}$ (1964). The average annual maximum temperature is 19.65 , the maximum is $20.63^{\circ} \mathrm{C}(2002)$, the minimum is $17.24^{\circ} \mathrm{C}(1964)$. The average annual minimum temperature is $8.05^{\circ} \mathrm{C}$, the maximum value is $9.41^{\circ} \mathrm{C}(2007)$, the minimum is $6.59^{\circ} \mathrm{C}(1969)$. The average temperature, average annual maximum temperature and average annual minimum temperature change trend of Weixian from 1961 to 2014 are shown in Table 1.

Figure 1 shows the annual mean temperature anomalies in Weixian County for nearly 54 years. As can be seen from the figure, Weixian County, the past 54 years, the average temperature was on the rise. It is shown in Table 1 that the average increase is $0.141^{\circ} \mathrm{C}$ every 10 years, and the test of significance of $\alpha=0.05$ is adopted, and the amplitude is less than $0.216^{\circ} \mathrm{C} / 10$ years in North China [6]. Weixian annual average temperature changes have obvious volatility. Before 1975, the temperature was at a low level. In 1976-1983, positive anomalies were more than negative anomalies. Beginning in 1984, the temperature is in a significant rise. Around 2010, the temperature is in the low period. 
Table 1. Annual average temperature, annual average maximum temperature and annual average minimum temperature trend.

\begin{tabular}{cccc}
\hline & $\begin{array}{c}\text { Annual average } \\
\text { temperature }\end{array}$ & $\begin{array}{c}\text { Average annual } \\
\text { maximum temperature }\end{array}$ & $\begin{array}{c}\text { Annual average } \\
\text { minimum temperature }\end{array}$ \\
\hline Trend rate $\left({ }^{\circ} \mathrm{C} / 10\right.$ years $)$ & $0.141^{*}$ & 0.056 & $0.247^{*}$ \\
Correlation coefficient & 0.425 & 0.136 & 0.567 \\
\hline
\end{tabular}

${ }^{*}$ By the test of significance of $\alpha=0.05$.

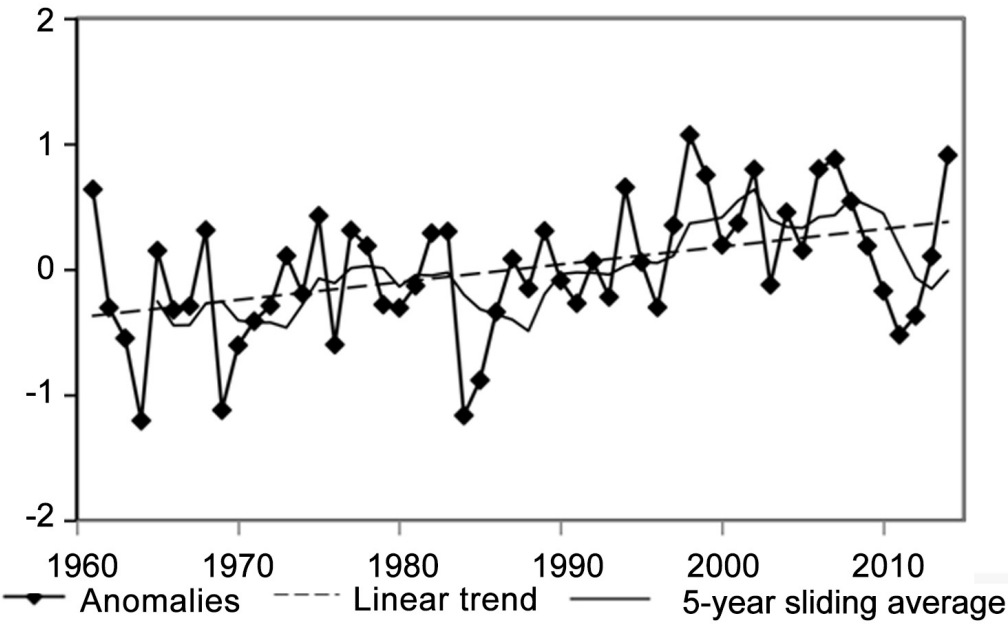

Figure 1. The variation of annual mean temperature anomalies $\left({ }^{\circ} \mathrm{C}\right)$.

Figure 2 shows the annual mean maximum temperature anomalies in the past 54 years. As it can be seen from the figure, in the Weixian County, the past 54 years, the average annual maximum temperature was on the rise. As can be seen from Table 1, the average increase of $0.056^{\circ} \mathrm{C}$ every 10 years, there is no test of significance by $\alpha=0.05$.

Figure 3 shows that the annual mean minimum temperature anomalies in Weixian County for nearly 54 years. It can be seen from the figure, Weixian County, the last 54 years, the average annual minimum temperature showed a significant upward trend. As shown in Table 1 , the average temperature rise is $0.247^{\circ} \mathrm{C}$ every ten years, and the temperature rise is larger, and the test of significance of $\alpha=0.05$ is adopted. Beginning in the mid-1980s, the minimum temperature entered a clear upward channel, warming significantly.

\subsection{Spring Air Temperature Characteristics}

The average temperature in spring is $14.35^{\circ} \mathrm{C}$, the maximum is $16.62^{\circ} \mathrm{C}(2014)$, the minimum is $12.35^{\circ} \mathrm{C}(1964)$. The average spring maximum temperature is 19.65 , the maximum is $23.42^{\circ} \mathrm{C}$ (1961), the minimum is $17.38^{\circ} \mathrm{C}$ (1964). The average minimum temperature in spring is $8.13^{\circ} \mathrm{C}$, the maximum is $10.65^{\circ} \mathrm{C}(2014)$, the minimum is $6.39^{\circ} \mathrm{C}$ (1962). The average temperature, the average spring maximum temperature and the spring average minimum temperature change trend in Weixian from 1961 to 2014 are shown in Table 2. 


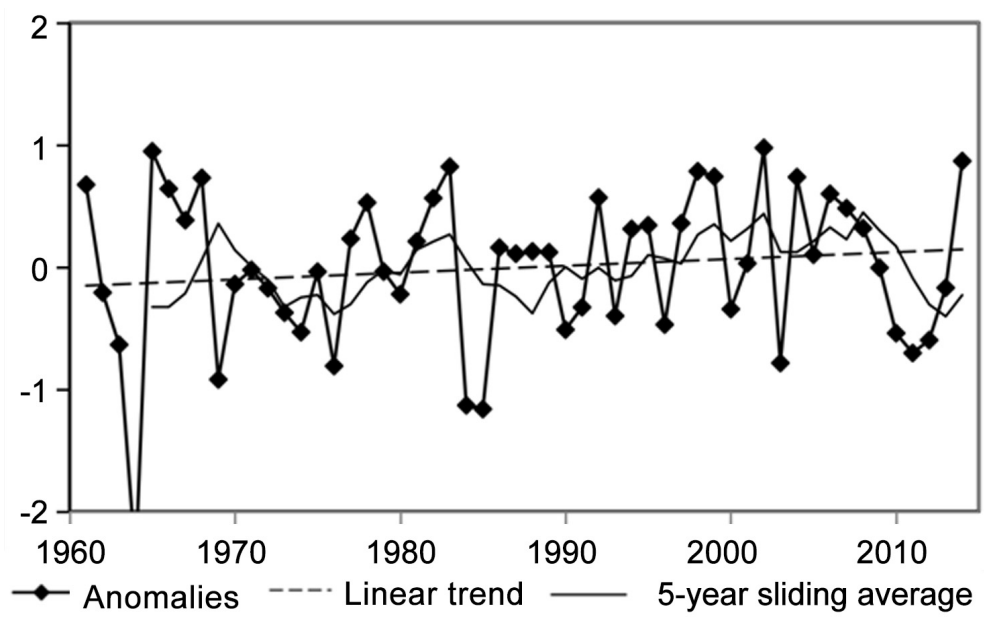

Figure 2. Annual average maximum temperature anomaly $\left({ }^{\circ} \mathrm{C}\right)$.

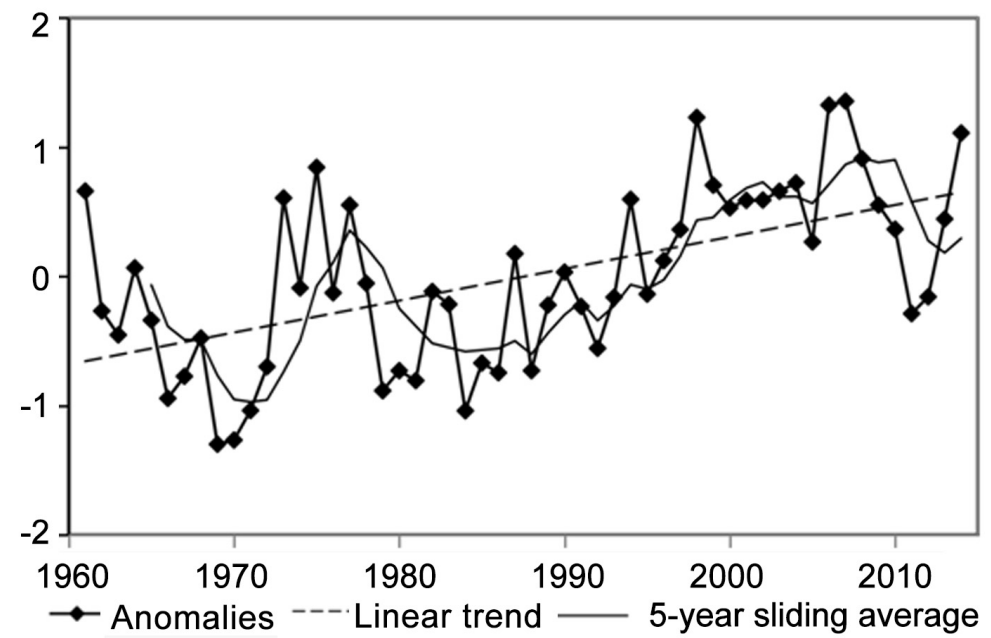

Figure 3. Variation characteristics of annual mean minimum temperature anomaly $\left({ }^{\circ} \mathrm{C}\right)$.

Table 2. Trends of spring mean air temperature, spring average maximum air temperature and spring average minimum air temperature.

\begin{tabular}{cccc}
\hline & $\begin{array}{c}\text { Spring average } \\
\text { temperature }\end{array}$ & $\begin{array}{c}\text { Spring average } \\
\text { maximum temperature }\end{array}$ & $\begin{array}{c}\text { Spring average } \\
\text { minimum temperature }\end{array}$ \\
\hline Trend rate $\left({ }^{\circ} \mathrm{C} / 10\right.$ years $)$ & $0.225^{*}$ & 0.099 & $0.392^{\star}$ \\
Correlation coefficient & 0.349 & 0.121 & 0.605 \\
\hline
\end{tabular}

${ }^{*}$ By the test of significance of $\alpha=0.05$.

Figure 4 shows the anomalies of the average temperature in Weixian County during the past 54 years. It can be seen from the figure, Weixian County, the past 54 years, the average temperature was rising in spring. From Table 2, it is found that the average value is $0.225^{\circ} \mathrm{C}$ every 10 years, and the test of significance of $\alpha=0.05$ is adopted, which is higher than the average annual temperature increase $\left(0.141^{\circ} \mathrm{C} / 10\right.$ years $)$. From 1960 
to 1980 , the temperature changed greatly. After 1998, most of the temperature were above the average.

Figure 5 shows the anomalous variation of the mean maximum temperature in Weixian County during the last 54 years. It can be seen from the figure, Weixian County, the last 54 years, the average temperature in the spring recorded the highest trend. It is known from Table 2 that the average temperature rise is $0.099^{\circ} \mathrm{C}$ every 10 years, and the temperature increase is small, and the test of significance of $\alpha=0.05$ is not adopted.

Figure 6 shows that the anomalies of the average minimum temperature in the spring of Weixian County in the past 54 years. As can be seen from the figure, the average minimum temperature in the past 54 years in Weixian County has a significant upward trend. From Table 2, the average annual increase of $0.392^{\circ} \mathrm{C}$, through the $\alpha=$ 0.05 the test of significance, higher than the average annual minimum temperature increase $\left(0.247^{\circ} \mathrm{C} / 10\right.$ years $)$. Before 1996 , negative anomalies dominated. After 1996 the temperature increased significantly, most of the year positive anomalies.

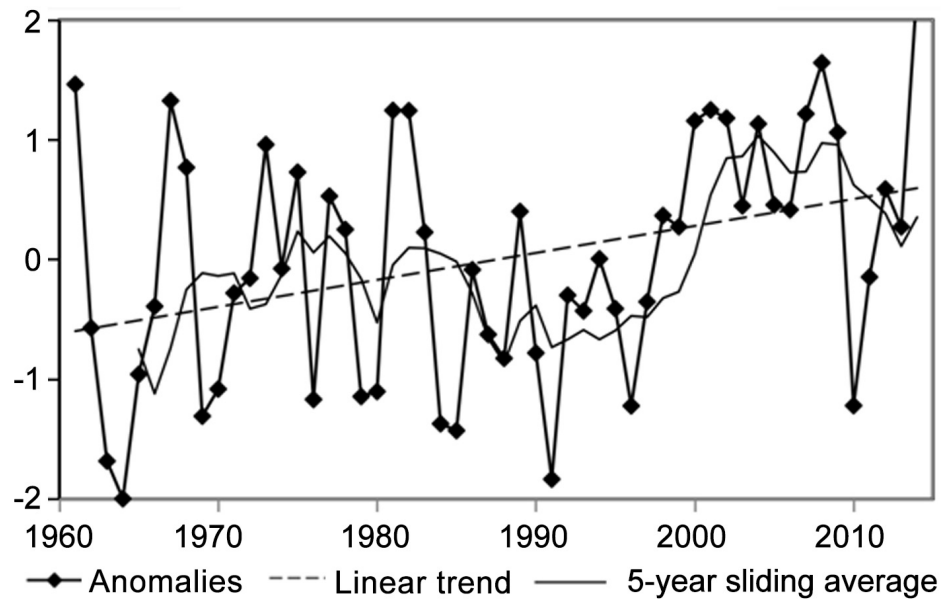

Figure 4. Change of mean temperature anomalies in spring $\left({ }^{\circ} \mathrm{C}\right)$.

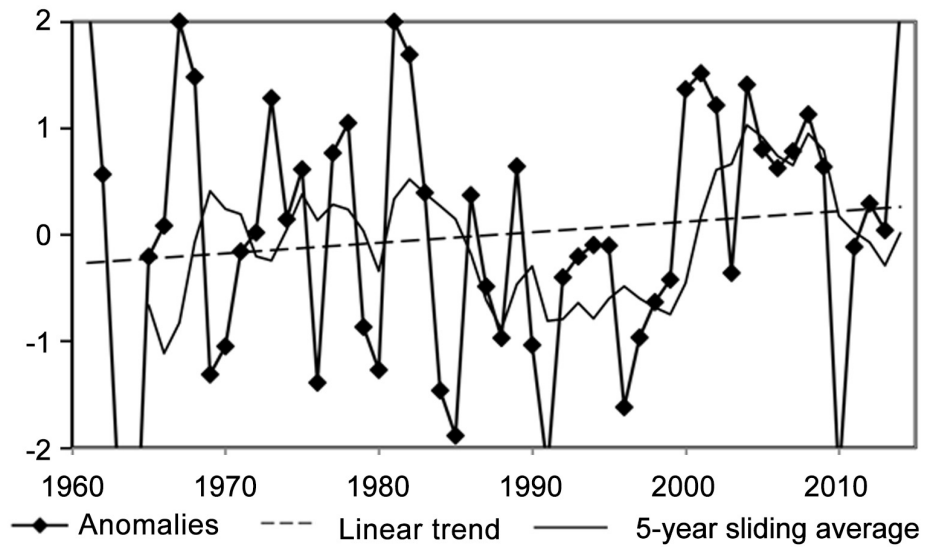

Figure 5. Variation characteristics of mean maximum temperature anomalies in spring $\left({ }^{\circ} \mathrm{C}\right)$. 


\subsection{The Characteristics of Summer Temperature Changes}

The average summer temperature in Weixian County is $26.22^{\circ} \mathrm{C}$, the maximum is $27.49^{\circ} \mathrm{C}$ (1997), the minimum is $24.88^{\circ} \mathrm{C}$ (2004). The average maximum temperature in summer is 31.69 , the maximum is $33.76^{\circ} \mathrm{C}$ (1968), the minimum is $30.23^{\circ} \mathrm{C}(2004)$. The average summer minimum temperature is $21.24^{\circ} \mathrm{C}$, the maximum is $22.54^{\circ} \mathrm{C}(2013)$, the minimum is $20.19^{\circ} \mathrm{C}$ (1989). The trend of average temperature, mean summer maximum temperature and average summer minimum temperature in Weixian from 1961 to 2014 are shown in Table 3.

Figure 7 shows the anomalous variation of summer mean temperature in Weixian County in the past 54 years. It can be seen from the figure, Weixian County, the past 54 years, the average summer temperature had a downward trend. As shown in Table 3, the average decrease of $0.052^{\circ} \mathrm{C}$ every 10 years, there is no test of significance by $\alpha=$ 0.05 , the smaller the change, a slow decline.

Figure 8 shows the anomalous variation of the average summer maximum temperature in Weixian County during the past 54 years. As can be seen from the figure, Weixian County, the past 54 years, the average summer maximum temperature showed a

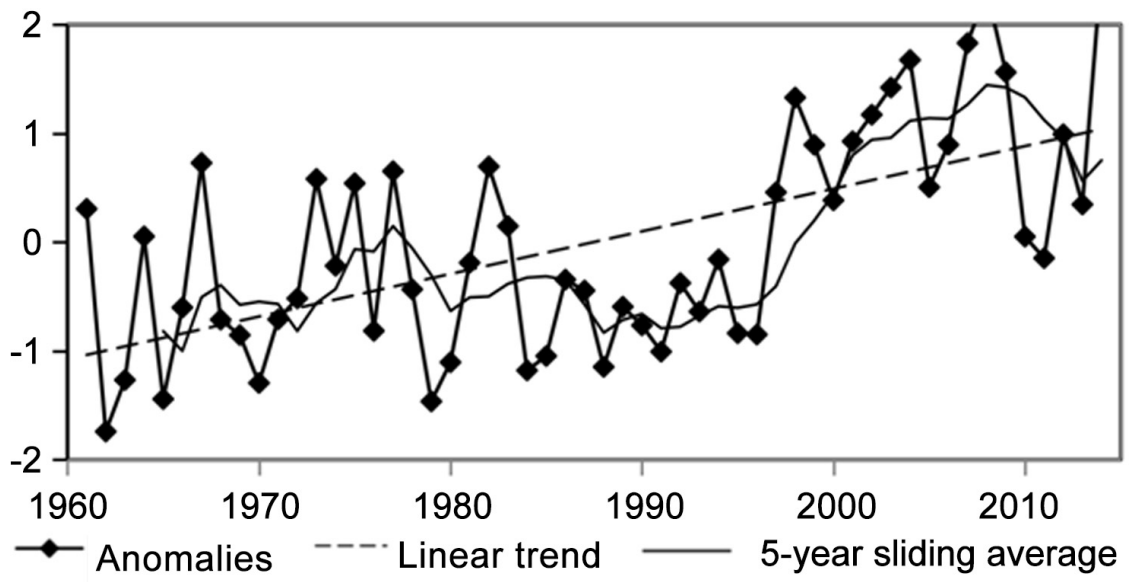

Figure 6. Change of mean minimum temperature anomaly in spring $\left({ }^{\circ} \mathrm{C}\right)$.

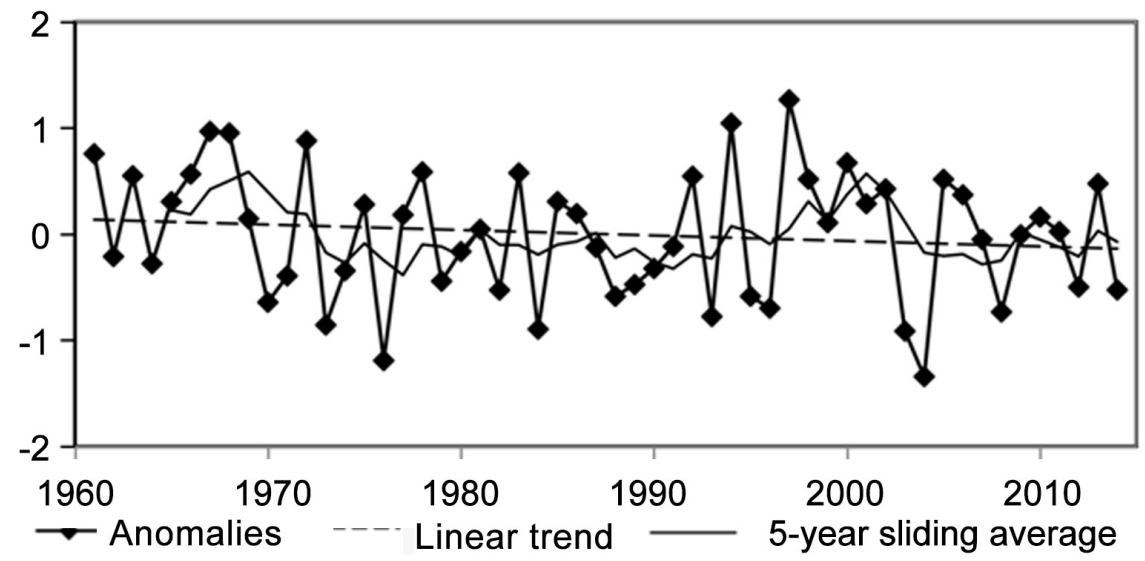

Figure 7. Variation of mean temperature anomalies in summer $\left({ }^{\circ} \mathrm{C}\right)$. 
Table 3. Trendsof summer mean air temperature, summer average maximum air temperature and summer mean minimum air temperature.

\begin{tabular}{cccc}
\hline & $\begin{array}{c}\text { Summer average } \\
\text { temperature }\end{array}$ & $\begin{array}{c}\text { Summer average } \\
\text { maximum temperature }\end{array}$ & $\begin{array}{c}\text { Summer average } \\
\text { minimum temperature }\end{array}$ \\
\hline Trend rate $\left({ }^{\circ} \mathrm{C} / 10\right.$ years $)$ & -0.052 & $-0.175^{*}$ & $0.124^{*}$ \\
Correlation coefficient & -0.133 & -0.315 & 0.327 \\
\hline
\end{tabular}

${ }^{*}$ By the test of significance of $\alpha=0.05$.

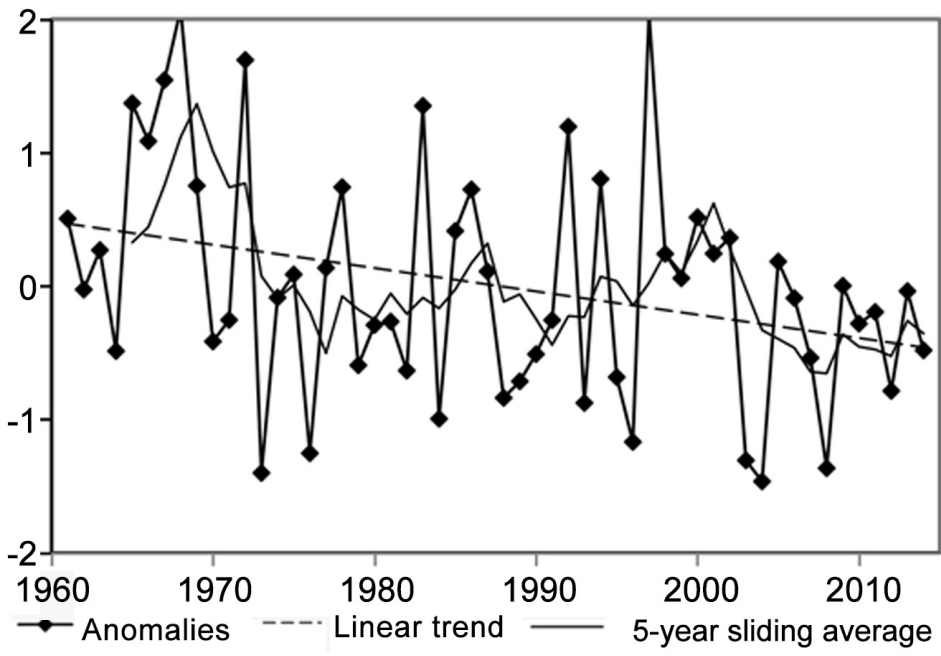

Figure 8. Variation characteristics of mean maximum temperature anomalies in summer $\left({ }^{\circ} \mathrm{C}\right)$.

significant downward trend. It is known from Table 3 that the average value is $0.175^{\circ} \mathrm{C}$ for every 10 years, and the test of significance with $\alpha=0.05$ is adopted. From 1960 to 2000, the temperature changed greatly. After 2000, the change is small, and negative anomalies are more.

Figure 9 shows the anomalies of the mean minimum temperature in Weixian County in the last 54 years. As can be seen from the figure, Weixian County, the last 54 years, the average summer minimum temperature was increased. It is shown in Table 3 that the average annual increase of $0.124^{\circ} \mathrm{C}$ for 10 years has passed the test of significance of $\alpha=0.05$, which is lower than the average annual minimum temperature increase $\left(0.247^{\circ} \mathrm{C} / 10\right.$ years $)$ and spring average minimum temperature increase $\left(0.392^{\circ} \mathrm{C} / 10\right.$ years). From 1960 to 1994, the temperature changed little, showing a slow descending trend. After 1994, the volatility is bigger, the temperature increase is bigger.

\subsection{The Characteristics of Autumn Air Temperature Changes}

The average temperature in autumn is $13.90^{\circ} \mathrm{C}$, the maximum is $16.03^{\circ} \mathrm{C}(1998)$, the minimum is $12.69^{\circ} \mathrm{C}(2009)$. The average maximum temperature in autumn is 20.33 , the maximum is $22.59^{\circ} \mathrm{C}(1998)$, and the minimum is $18.17^{\circ} \mathrm{C}(1962)$. The autumn average minimum temperature is $8.56^{\circ} \mathrm{C}$, the maximum is $10.44^{\circ} \mathrm{C}(2006)$, the minimum is $6.22^{\circ} \mathrm{C}(1979)$. The trend of average temperature, autumn average maximum tem- 
perature, and autumn mean minimum temperature trends in the autumn of 1961 to 2014 are shown in Table 4.

Figure 10 shows the anomalies of the average temperature in the autumn of Weixian County in the past 54 years. As can be seen from the figure, Weixian County, the last 54

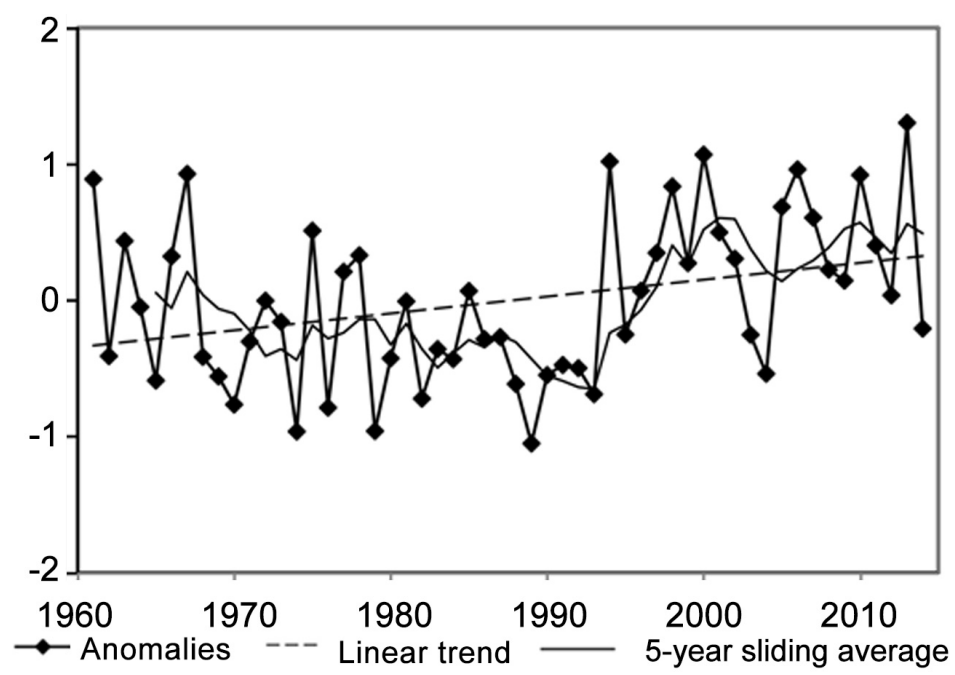

Figure 9. Variation characteristics of mean minimum temperature anomalies in summer $\left({ }^{\circ} \mathrm{C}\right)$.

Table 4. Trends of autumn mean air temperature, autumn average maximum air temperature and autumn mean minimum air temperature.

\begin{tabular}{cccc}
\hline & $\begin{array}{c}\text { Autumn average } \\
\text { temperature }\end{array}$ & $\begin{array}{c}\text { Autumn average } \\
\text { maximum temperature }\end{array}$ & $\begin{array}{c}\text { Autumn average } \\
\text { minimum temperature }\end{array}$ \\
\hline Trend rate $\left({ }^{\circ} \mathrm{C} / 10\right.$ years $)$ & 0.116 & 0.179 & 0.104 \\
Correlation coefficient & 0.253 & 0.266 & 0.167 \\
\hline
\end{tabular}

${ }^{\star}$ By the test of significance of $\alpha=0.05$.

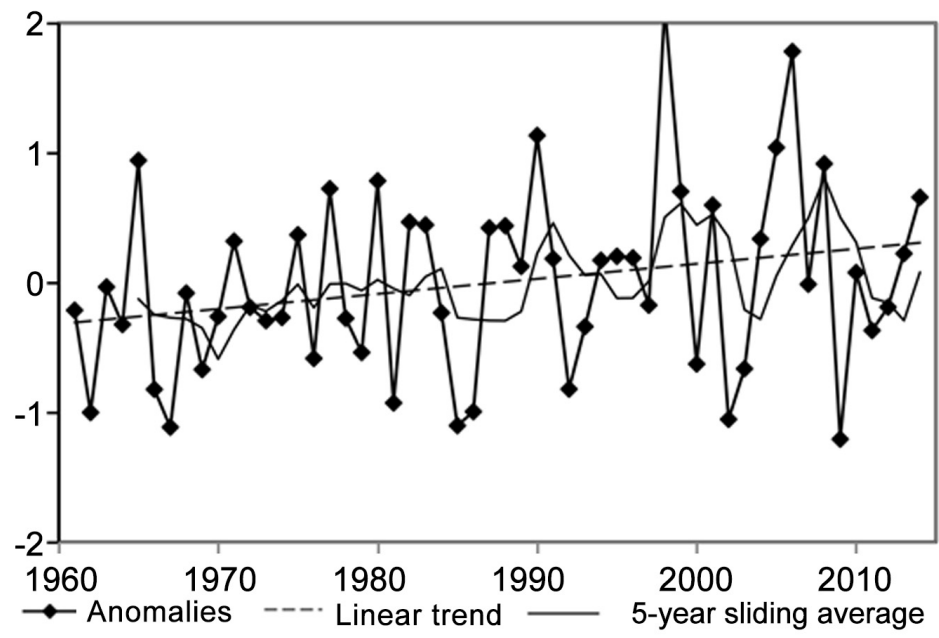

Figure 10. Variation of mean temperature anomalies in autumn $\left({ }^{\circ} \mathrm{C}\right)$. 
years the average temperature rose in the fall trend. From Table 4, we know that the average increase of $0.116^{\circ} \mathrm{C}$ every 10 years, there is no test of significance by $\alpha=0.05$, the smaller the variation, showing a slow warming trend.

Figure 11 shows that the anomalous variation of the mean maximum temperature in Weixian County during the last 54 years. As can be seen from the figure, Weixian County, the last 54 years, the highest average temperature in autumn was an increasing trend. As can be seen from Table 4, the average increase is $0.179^{\circ} \mathrm{C}$ every 10 years, and there is no test of significance for $\alpha=0.05$. The temperature was fluctuating rise.

Figure 12 shows the anomalous variation of the mean minimum temperature in Weixian County during the last 54 years. It can be seen from the figure, Weixian County, the last 54 years, the average temperature in autumn was the trend of warming. As shown in Table 4, the average increase of $0.104^{\circ} \mathrm{C}$ for every 10 years has not passed the test of significance of $\alpha=0.05$, which is lower than that of the average annual minimum temperature increase $\left(0.247^{\circ} \mathrm{C} / 10\right.$ years $)$ and spring average minimum temperature increase $\left(0.392^{\circ} \mathrm{C} / 10\right.$ years).

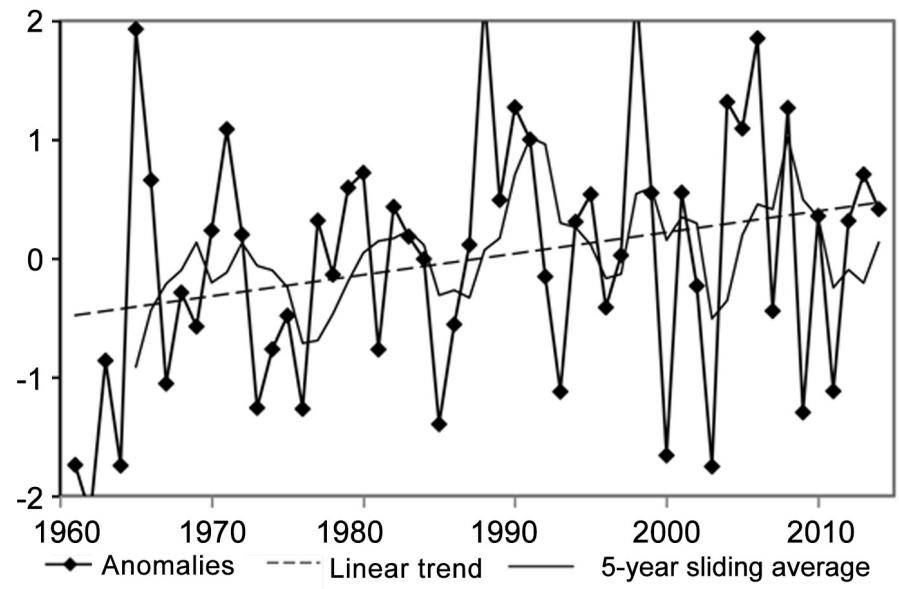

Figure 11. Variation of the mean maximum temperature anomalies in autumn $\left({ }^{\circ} \mathrm{C}\right)$.

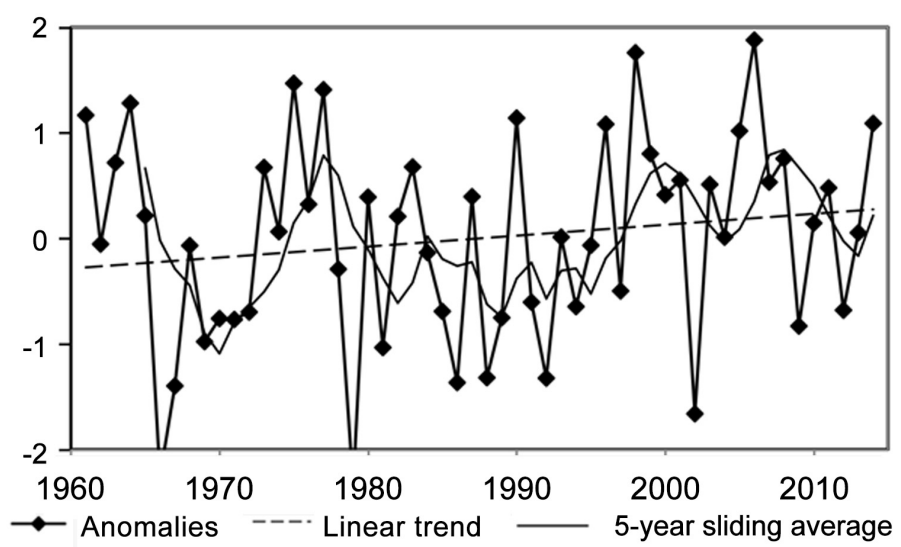

Figure 12. Change in the mean minimum temperature anomalies in autumn $\left({ }^{\circ} \mathrm{C}\right)$. 


\subsection{Winter Temperature Changes}

The average winter temperature in Weixian County is $-1.09^{\circ} \mathrm{C}$, the maximum is $1.59^{\circ} \mathrm{C}$ (2001), the minimum is $-3.91^{\circ} \mathrm{C}(1971)$. The average winter maximum temperature is $5.14^{\circ} \mathrm{C}$, the maximum is $8.38^{\circ} \mathrm{C}(2001)$, the minimum is $1.31^{\circ} \mathrm{C}(1963)$. The average minimum temperature in winter is $-6.04^{\circ} \mathrm{C}$, the maximum is $-3.89^{\circ} \mathrm{C}(2001)$, the minimum is $-9.86^{\circ} \mathrm{C}(1967)$. The trend of average winter temperature, average winter maximum temperature and average winter minimum temperature in Weixian from 1961 to 2014 are shown in Table 5.

Figure 13 shows the anomalies of winter mean air temperature in Weixian County for nearly 54 years. It can be seen from the figure, Weixian County, the past 54 years, the average winter temperature was a sharp upward trend. From Table 5, the average annual increase of $0.293^{\circ} \mathrm{C}$ per 10 years, the average annual temperature increase of 2.08 times, through the $\alpha=0.05$ the test of significance. Before 1985, negative anomalies fluctuated. After 1985, the main positive anomalies, and fluctuations.

Figure 14 shows the anomalies of the average maximum winter temperature in Weixian during the past 54 years. It can be seen from the figure, Weixian County, the past 54 years, the average winter maximum temperature showed a slow upward trend. As can be seen from Table 5, the average increase of $0.185^{\circ} \mathrm{C}$ every 10 years, there is no test of significance by $\alpha=0.05$. The temperature showed a great change.

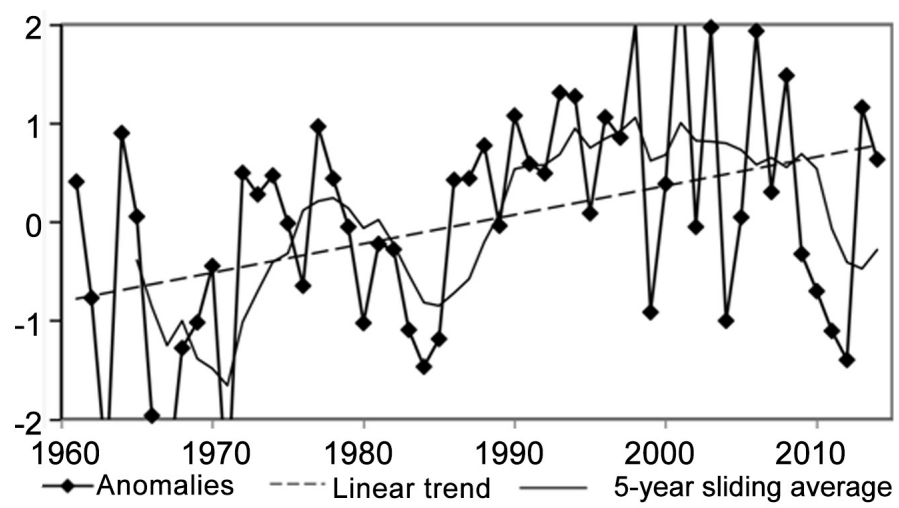

Figure 13. Variation of mean temperature anomalies in winter $\left({ }^{\circ} \mathrm{C}\right)$.

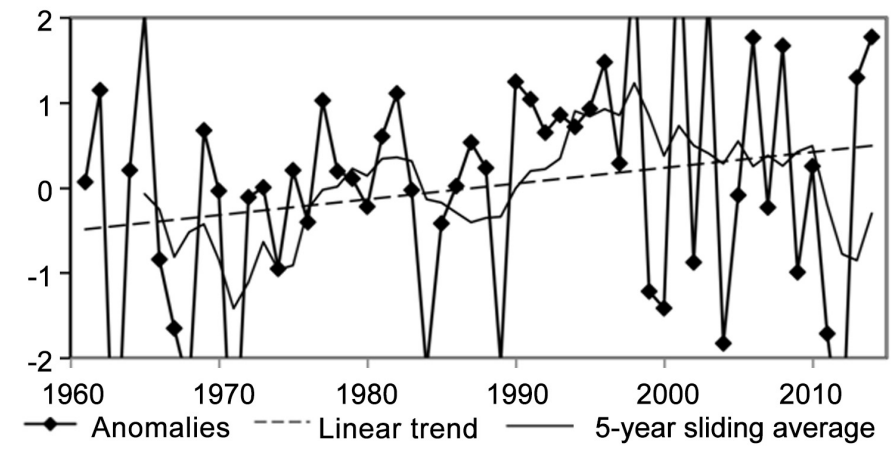

Figure 14. Variation of mean maximum temperature anomalies in winter $\left({ }^{\circ} \mathrm{C}\right)$. 
Figure 15 shows the anomalies of the winter minimum mean temperature over the past 54 years. As can be seen from the figure, Weixian County, the last 54 years, the average winter minimum temperature showed a significant upward trend. It is shown in Table 5 that the average temperature rise is $0.356^{\circ} \mathrm{C}$ every 10 years, which is higher than the average annual minimum temperature increase $0.247^{\circ} \mathrm{C} / 10$ years, which is smaller than that of spring average temperature increase $0.392^{\circ} \mathrm{C} / 10$ years. After 1985, the temperature showed a leaping rise, and the duration is longer.

\subsection{Accumulated Temperature Changes}

Accumulation temperature is a measure of regional calorie conditions can meet the criteria for crop growth and development and has significant importance agricultural production. This article accumulated temperature by referring to the effective accumulated temperature, defined as the sum of the daily mean temperature between the end of the day, using a five-day moving average method to determine the stability of a year through the threshold temperature of the beginning and ending dates. In the past 54 years, the average $\geq 0^{\circ} \mathrm{C}$ accumulated temperature of Wenxian was $5090.90^{\circ} \mathrm{C}$, the maximum value was $5412.3^{\circ} \mathrm{C}(1998)$, the minimum value was $4780.8^{\circ} \mathrm{C}(1964) . \geq 10^{\circ} \mathrm{C}$ accumulated temperature average is $2492.85^{\circ} \mathrm{C}$, the maximum is $2716.5^{\circ} \mathrm{C}$ (1998), the minimum is $2289.3^{\circ} \mathrm{C}$ (1964). The rate of accumulated temperature trend is shown in Table 6.

Figure 16 shows the anomalies of the accumulated temperature over the past 54 years in Weixian County. It can be seen from the figure that the accumulative temperature of Weixian County has risen in recent 54 years. Since 1993, the rise has been

Table 5. Average winter temperature, average winter maximum temperature and average winter minimum temperature trend.

\begin{tabular}{cccc}
\hline & $\begin{array}{c}\text { Winter average } \\
\text { temperature }\end{array}$ & $\begin{array}{c}\text { Average winter } \\
\text { maximum temperature }\end{array}$ & $\begin{array}{c}\text { Average winter } \\
\text { minimum temperature }\end{array}$ \\
\hline Trend rate $\left({ }^{\circ} \mathrm{C} / 10\right.$ years $)$ & $0.293^{*}$ & 0.185 & $0.356^{*}$ \\
Correlation coefficient & 0.389 & 0.194 & 0.381
\end{tabular}

${ }^{*}$ By the test of significance of $\alpha=0.05$.

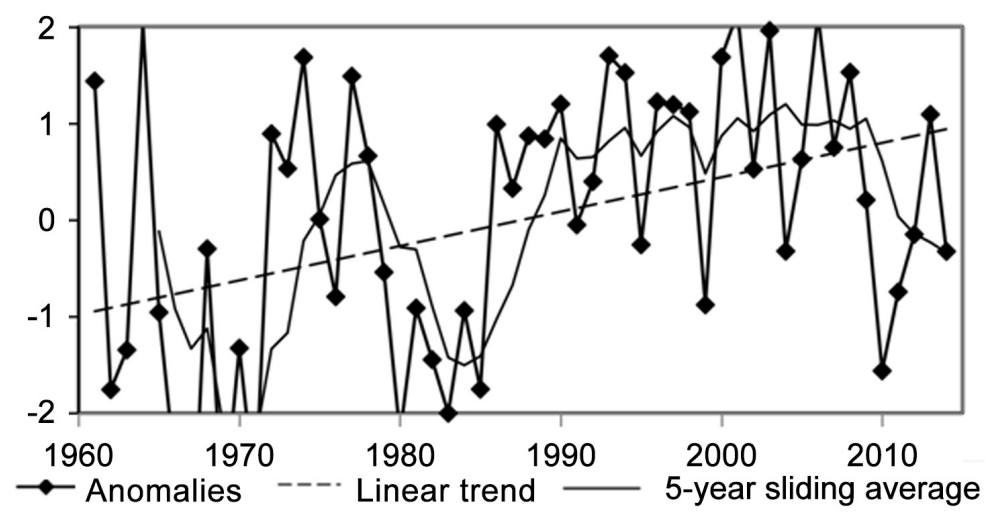

Figure 15. Variation of mean minimum temperature anomalies in winter $\left({ }^{\circ} \mathrm{C}\right)$. 
quick. The average increase of $35.892^{\circ} \mathrm{C}$ every 10 years, through the $\alpha=0.05$ test of significance.

Figure 17 shows the anomalies of the accumulated temperature over 10 years in Weixian County. Can be seen from the figure, Weixian County, the past 54 years $\geq 10^{\circ} \mathrm{C}$ accumulated temperature slowly increased. As can be seen from Table 6, the average increase of $15.295^{\circ} \mathrm{C}$ every 10 years, there is no test of significance by $\alpha=0.05$.

\subsection{Changes in Sunshine Hours}

In the past 54 years, the average sunshine duration in Weixian County was $2375.8 \mathrm{~h}$, the maximum value was $3206.1 \mathrm{~h}$ (1965), and the minimum value was $1728.9 \mathrm{~h}$ (1991).

Table 6. Average winter temperature, average winter maximum temperature and average winter minimum temperature trend.

\begin{tabular}{ccc}
\hline & $\geq 0{ }^{\circ} \mathrm{C}$ Accumulated temperature & $\geq 10^{\circ} \mathrm{C}$ Accumulated temperature \\
\hline Trend rate $\left({ }^{\circ} \mathrm{C} / 10\right.$ years $)$ & $35.892^{*}$ & 15.295 \\
Correlation coefficient & 0.381 & 0.244 \\
\hline
\end{tabular}

${ }^{*}$ By the test of significance of $\alpha=0.05$.

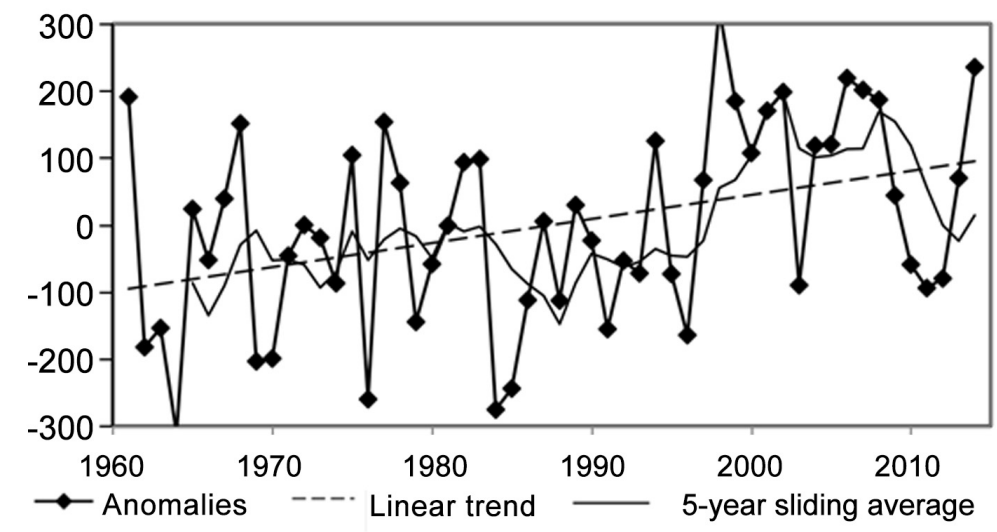

Figure $16 . \geq 0{ }^{\circ} \mathrm{C}$ effective accumulated temperature change charactestics $\left({ }^{\circ} \mathrm{C}\right)$.

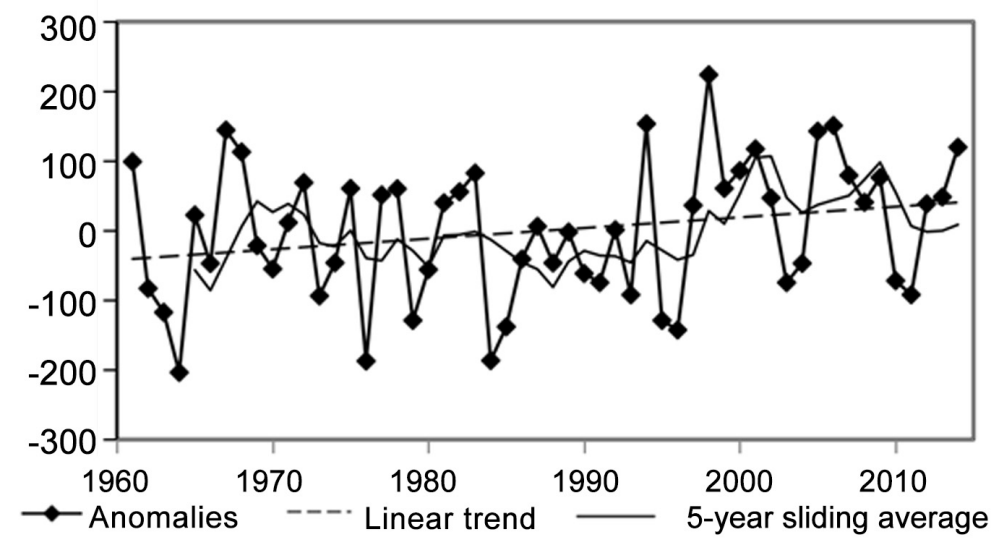

Figure $17, \geq 10^{\circ} \mathrm{C}$ effective accumulated temperature change characteristics $\left({ }^{\circ} \mathrm{C}\right)$. 
The average sunshine percentage is $53.83 \%$, the maximum is $72 \%$ (1965), the minimum is $40 \%$ (1991). The rate of change is shown in Table 7.

Figure 18 shows the variation of sunshine duration in Weixian County during the past 54 years. It can be seen that, in 1981 and 1993 for the sector, sunshine hours decreased significantly in three stages. As can be seen from Table 7, the downward trend rate is $119.121 \mathrm{~h} / 10$ years, and the test of significance with $\alpha=0.05$ is adopted. The change in sunshine percentage is the same as the sunshine hours.

\subsection{Characteristics of Annual Precipitation Variation}

In the past 54 years, the average annual precipitation of Weixian County is $525.8 \mathrm{~mm}$, the annual maximum precipitation is $1288.2 \mathrm{~mm}$ in 1973, and the annual minimum precipitation is $225.1 \mathrm{~mm}$ in 1992. The maximum daily precipitation is $84.18 \mathrm{~mm}$, the maximum daily precipitation is $302.6 \mathrm{~mm}$ on August 4, 1993, and the minimum is 29.5 $\mathrm{mm}$ on June 15,1999 . The average number of annual precipitation days is 84.67 , the max annual precipitation days is 113 days in 1965, and the annual precipitation days is the lowest in 56 days in 2013. The rate of change is shown in Table 8.

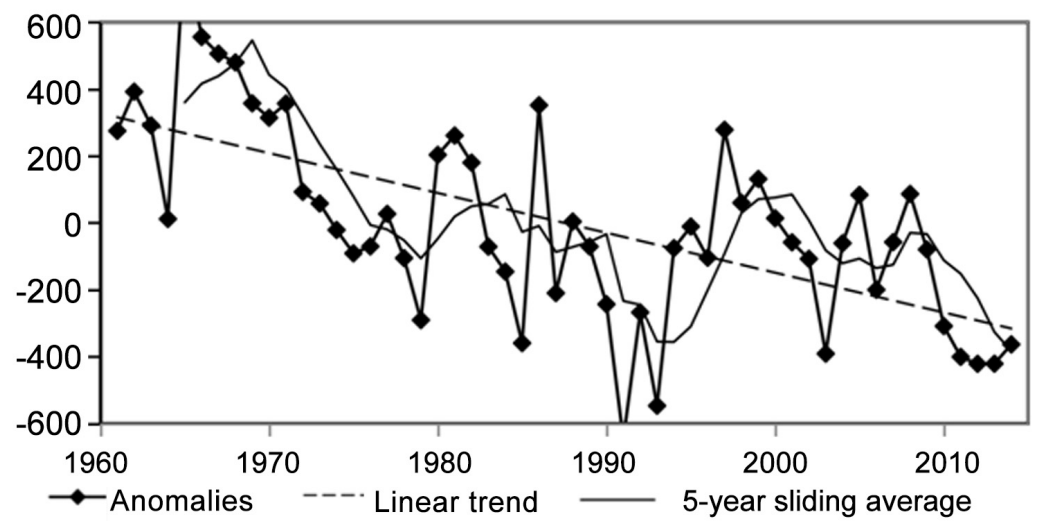

Figure 18. Characteristics of sunshine duration variations (h).

Table 7. Sunshine hours, sunshine percentage change trend rate.

\begin{tabular}{ccc}
\hline & Sunshine hours & Sunshine percentage \\
\hline Trend (h / 10 years) & $-119.121^{*}$ & $-2.729^{*}$ \\
Correlation coefficient & -0.630 & -0.650 \\
\hline
\end{tabular}

${ }^{*}$ By the test of significance of $\alpha=0.05$.

Table 8. Annual precipitation, daily maximum precipitation, and annual precipitation days.

\begin{tabular}{cccc}
\hline & Annual precipitation & $\begin{array}{c}\text { Daily maximum } \\
\text { precipitation }\end{array}$ & Annual rain days \\
\hline Trend rate $(\mathrm{mm} / 10$ years $)$ & -21.557 & -1.519 & $-3.441^{\star}(\mathrm{d} / 10$ year $)$ \\
Correlation coefficient & -0.188 & -0.054 & -0.476 \\
\hline
\end{tabular}

${ }^{*}$ By the test of significance of $\alpha=0.05$. 
Figure 19 shows the annual precipitation anomalies in Weixian County in the past 54 years. It can be seen from the figure that before 1978, annual precipitation increased slowly. After 1978, the precipitation decreased gradually, the trend of decreasing trend was $21.557 \mathrm{~mm} / 10$ years, which was much higher than that of Zibo, Shandong, China, which was $2.18 \mathrm{~mm} / 10$ years [12].

Figure 20 shows the variation of the maximum daily precipitation in Weixian County in the past 54 years. It can be seen from the figure that before 2000, the maximum annual precipitation fluctuates greatly. After 2000, the fluctuation is small, and most of them are in negative anomaly. The trend is $-1.519 \mathrm{~mm} / 10$ years, and the test of significance of $\alpha=0.05$ is not carried out.

Figure 21 shows the annual precipitation days anomalies in Weixian County in the past 54 years. It can be seen from the figure that the number of annual precipitation days is generally less and the trend rate is $-3.441 \mathrm{~d} / 10$ years, and the test of significance of $\alpha=0.05$ is adopted.

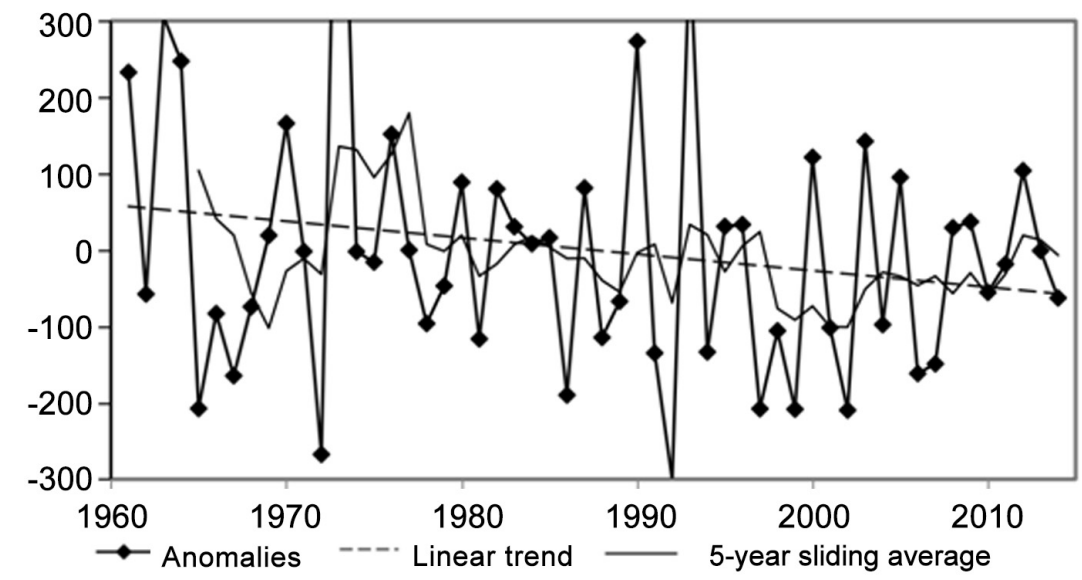

Figure 19. Characteristics of annual precipitation variations ( $\mathrm{mm})$.

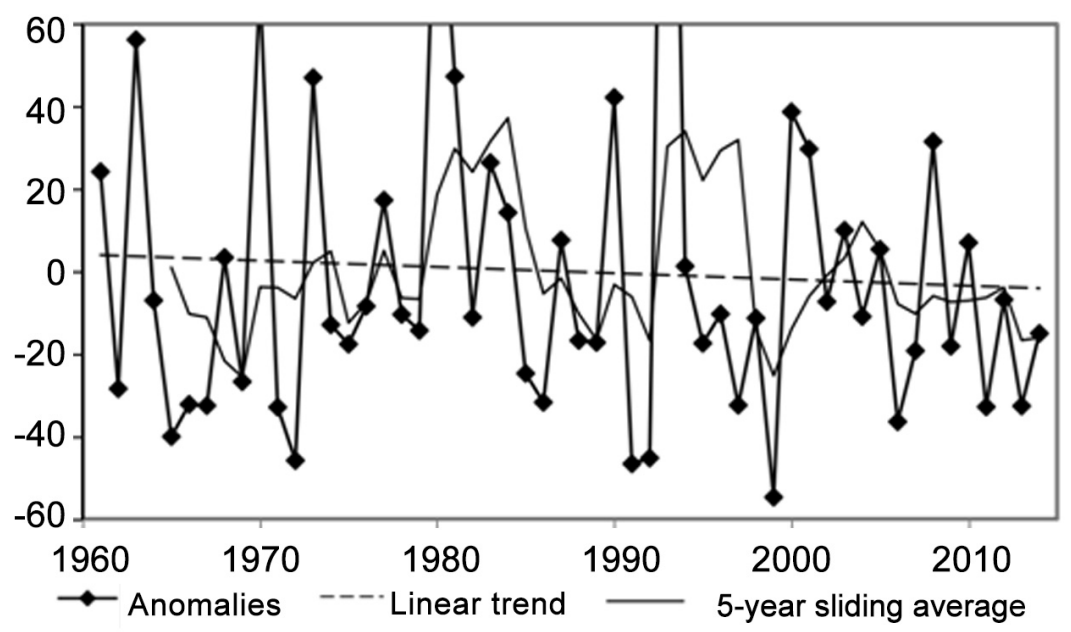

Figure 20. Daily maximum precipitation variations $(\mathrm{mm})$. 


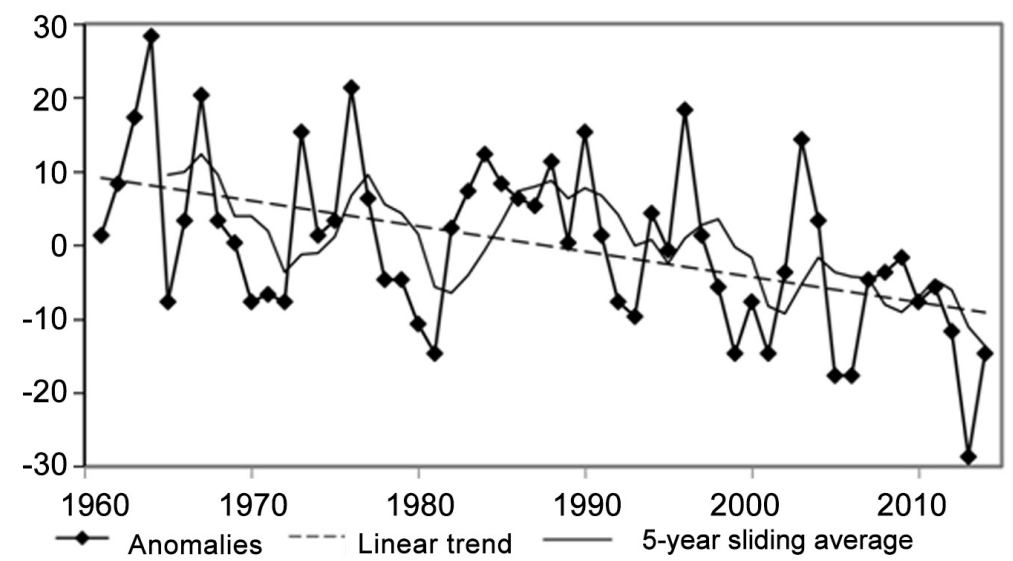

Figure 21. Characteristics of annual precipitationdays variation.

\section{Conclusions}

Based on the statistical analysis of climatological data of Weixian County for 54 years from 1961 to 2014, the following conclusions are obtained:

1) Weixian annual average temperature, annual average maximum temperature, average annual minimum temperature showed a significant rising trend. The trend rates were $0.141^{\circ} \mathrm{C} / 10$ years, $0.056^{\circ} \mathrm{C} / 10$ years and $0.247^{\circ} \mathrm{C} / 10$ years. The annual average temperature and the annual average minimum temperature have passed the test of significance. The annual average minimum temperature increased the most in 54 years, warming $1.33^{\circ} \mathrm{C}$.

2) The results of all seasons show that except for the average temperature and average maximum temperature in summer, there is a tendency to increase. The average temperature was the most obvious in winter $\left(0.293^{\circ} \mathrm{C} / 10\right.$ years $), 1.58^{\circ} \mathrm{C}$ in 54 years and $0.225^{\circ} \mathrm{C} / 10$ years in spring. The maximum temperature was the highest in winter $\left(0.185^{\circ} \mathrm{C} / 10\right.$ years $)$, followed by autumn $\left(0.179^{\circ} \mathrm{C} / 10\right.$ years $)$, but it did not pass the test of significance. The maximum temperature in summer decreased $\left(-0.175^{\circ} \mathrm{C} / 10\right.$ years $)$ and passed the test of significance, which indicated that the maximum temperature in Weixian County decreased gradually in summer and decreased by $0.95^{\circ} \mathrm{C}$ in 54 years. For the lowest temperature, the temperature increased the fastest in spring $\left(0.392^{\circ} \mathrm{C} / 10\right.$ years), increased by $2.12^{\circ} \mathrm{C}$ in 54 years, and followed by winter $\left(0.356^{\circ} \mathrm{C} / 10\right.$ years $)$ and summer $\left(124^{\circ} \mathrm{C} / 10\right.$ years). The above three items had passed the test of significance. The autumn minimum temperature change $\left(0.104^{\circ} \mathrm{C} / 10\right.$ years $)$ did not pass the test of significance.

3) The accumulated temperature of $\geq 0^{\circ} \mathrm{C}$ in Weixian County increased by $193.82^{\circ} \mathrm{C}$ in 54 years $\left(35.89^{\circ} \mathrm{C} / 10\right.$ years $)$ and passed the test of significance. It indicates an increase in heat and a prolonged growth season. This conclusion has certain reference to agricultural production and planting structure adjustment. The accumulated temperature of $\geq 10^{\circ} \mathrm{C}$ increased by $82.59^{\circ} \mathrm{C}\left(15.295^{\circ} \mathrm{C} / 10\right.$ years $)$. They did not pass the tests of significance, indicating that Weixian County temperature rose to $10^{\circ} \mathrm{C}$ below the main.

4) In 54 years, the sunshine duration of Weixian County decreased by $119.121 \mathrm{~h} / 10$ 
years, decreased by $643.25 \mathrm{~h}$ in 54 years, accounting for $27.1 \%$ of the average sunshine hours (2375.8 h/year). This has a negative impact on public life and crop growth.

5) Annual precipitation in Weixian County decreased by $116.4 \mathrm{~mm}$ for 54 years, and the maximum precipitation decreased by $8.2 \mathrm{~mm}$. The annual precipitation days decreased by 18.6 days, which caused great pressure on groundwater supply.

\section{Acknowledgements}

This paper is supported by the research project of Xingtai Meteorological Bureau, China, "Characteristics of agricultural climate change in Weixian County" (ID: 15xtky19).

\section{References}

[1] IPCC (2013) Climate Change 2013: The Physical Science Basis. Cambridge University Press, Cambridge.

[2] Second National Assessment Report on Climate Change (2011) The Preparation of the Second National Climate Change Assessment Report. Science Press, Beijing, 20-24.

[3] Ding, Y.H. and Dai, X.S. (1994) The Temperature Changes in China in the Past Hundred Years. Meteorology, 20, 19-26.

[4] Wang, C.H., Li, X. and Miao, Q.L. (2003) Characteristics of Daily Minimum Temperature Change in China in Recent 50 Years. Geographical Science, 23, 441-447.

[5] Gao, R., Guo, Z.X., Chen, S.Y., et al. (2009) Characteristics of Summer Monsoon Air Temperature Variation over Eastern China in Recent 46 Years. Geographical Science, 29, 255261.

[6] Guo, Z.M., Miao, Q.L. and Li, X. (2005) Characteristics of Temperature Change in Northern China in Recent 50 Years. Scientia Geographica Sinica, 25, 448-454.

[7] Hu, Y.C., Dong, W.J. and He, Y. (2007) Progress in Extreme Weather and Climate Events in Early 21st Century. Advances in Earth Science, 22, 1067-1075.

[8] Fang, S.B., Yang, J.J. and Zhou, G.S. (2011) Changes and Distribution Characteristics of Agrometeorological Disasters in China in Recent 30 Years. Journal of Natural Disasters, 20, 69-73.

[9] Zhao, S.H., Yang, Y.H., Qiu, G.Y., et al. (2007) Analysis of Climate Change Tendency in Hebei Plain in Recent 34 Years. Resources Science, 29, 109-113.

[10] Chen, Y.H., Zhang, A.Y., Guo, X.J., et al. (2009) Characteristics of Temperature Change in Recent 45 Years in Hebei Province. Shaanxi Meteorology, 29, 23-26.

[11] Liu, X.F., Ruan, X. and Li, Y.H. (2005) Analysis of Climatic Characteristics of Cold and Warm Change in Hebei Province. Meteorological Science, 25, 638-644.

[12] Liu, Y. and Huan, H.J. (2014) Zibo 60 Years Temperature and Precipitation Trends Analysis. Shandong Weather, 34, 28-31. 
Submit or recommend next manuscript to SCIRP and we will provide best service for you:

Accepting pre-submission inquiries through Email, Facebook, LinkedIn, Twitter, etc.

A wide selection of journals (inclusive of 9 subjects, more than 200 journals)

Providing 24-hour high-quality service

User-friendly online submission system

Fair and swift peer-review system

Efficient typesetting and proofreading procedure

Display of the result of downloads and visits, as well as the number of cited articles

Maximum dissemination of your research work

Submit your manuscript at: http://papersubmission.scirp.org/

Or contact gep@scirp.org 